Article

\title{
Journalism Students and Information Consumption in the Era of Fake News
}

\author{
Santiago Tejedor *, Marta Portalés-Oliva, Ricardo Carniel-Bugs and Laura Cervi \\ Department of Journalism and Communication Sciences, Autonomous University of Barcelona, 08193 Barcelona, Spain; \\ E-Mails: santiago.tejedor@uab.cat (S.T.), marta.portales@e-campus.uab.cat (M.P.-O.), ricardo.carniel@uab.cat (R.C.-B.), \\ laura.cervi@uab.cat (L.C.)
}

* Corresponding author

Submitted: 29 July 2020 | Accepted: 27 September 2020 | Published: 3 March 2021

\begin{abstract}
Technological platforms, such as social media, are disrupting traditional journalism, as a result the access to high-quality information by citizens is facing important challenges, among which, disinformation and the spread of fake news are the most relevant one. This study approaches how journalism students perceive and assess this phenomenon. The descriptive and exploratory research is based on a hybrid methodology: Two matrix surveys of students and a focus group of professors $(n=6)$, experts in Multimedia Journalism. The first survey $(n=252)$, focused on students' perception of fake news, the second $(n=300)$ aims at finding out the type of content they had received during the recent confinement caused by the Covid-19 pandemic. Results show that most of the students prefer online media as a primary source of information instead of social media. Students consider that politics is the main topic of fake news, which, according to the respondents, are mainly distributed by adult users through social networks. The vast majority believe that fake news are created for political interests and a quarter of the sample considers that there is a strong ideological component behind disinformation strategies. Nonetheless, the study also reveals that students do not trust in their ability to distinguish between truthful and false information. For this reason, this research concludes, among other aspects, that the promotion of initiatives and research to promote media literacy and news literacy are decisive in the training of university students.
\end{abstract}

\section{Keywords}

fake news; information consumption; journalism; media literacy; university

\section{Issue}

This article is part of the issue "Disinformation and Democracy: Media Strategies and Audience Attitudes" edited by Pere Masip (University Ramon Llull, Spain), Bella Palomo (University of Málaga, Spain) and Guillermo López (University of Valencia, Spain).

(C) 2021 by the authors; licensee Cogitatio (Lisbon, Portugal). This article is licensed under a Creative Commons Attribution 4.0 International License (CC BY).

\section{Introduction}

In recent years, fake news and misinformation have become a recurrent object of study both because of their rapid growth and because of the problems and threats, they generate. Since the emergence of this concept (Love, 2007; Tally, 2011), the first works have focused on political phenomena (Blanco Alfonso, García Galera, \& Tejedor Calvo, 2019) and have rapidly given way to research on the impact of fake news in other areas of our daily lives, such as education, entertainment, health and journalism, among others.

The popularization of fake news has taken place in a very particular informative and communicative situation, characterized by digital noise, 'infoxication' and information disorder (Wardle \& Derakhshan, 2017). Infoxication is a term popularized by Alvin Toffler (1970) that describes nowadays information overload derived from our constant connection to Internet. In this context, two very particular phenomena have occurred. On 
the one hand, the rapid distribution of this type of message (Jang \& Kim, 2018) and, on the other hand, the accelerated generation of a wide variety of distorted content (Ireland, 2018; Southwell, Thorson, \& Sheble, 2018). The studies by Fletcher, Cornia, Graves, and Rasmus (2018) and Musgrove, Powers, Rebar, and Musgrove (2018) emphasize the capacity and easiness by online platforms to spread fake news in comparison with conventional media. Thus, the so-called information society has given way to a society of infoxication or digital noise where fake news are disseminated $10 \%$ more than real news (Vosoughi, Roy, \& Aral, 2018).

Generation Z, composed of individuals born between the years 1996 and 2010 (Dimock, 2019), is the first generation that has never known a world without the Internet. Their lives are moulded by the Internet, which has been converted in a natural part of their lives. Nonetheless, numerous studies (Hargittai, Fullerton, Menchen-Trevino, \& Thomas, 2010; Wineburg \& McGrew, 2016) have highlighted that they are the most vulnerable to fake news.

Among today's Generation Zers, we find the journalists of tomorrow. Journalism and communication students represent a category of special interest, since besides belonging to the broader category of Generation Zers, soon will be in charge of taking up the responsibilities involved in the task of being a professional journalist and/or communicator.

Despite the interest that this subgroup of young people should arise, very few studies (Bhaskaran, Mishra, \& Nair, 2019) have focused on journalism students' understanding and perception of 'fake news.'

Herrero-Diz, Conde-Jiménez, Tapia-Frade, and Varona-Aramburu (2019), analyzing students of Communication from the Spanish region of Andalusia, conclude that university students have difficulty differentiating the veracity of the sources. Another study based in the Basque country (Mendiguren, Pérez Dasilva, \& Meso Ayerdi, 2020) observe that students are mainly informed in the online environment and a high percentage confesses to having fallen into the trap of fake news at some point.

Besides the mentioned studies, fake news and the way journalism students react to them are still an understudied topic, specifically, as Blanco Alfonso et al. (2019) point out, in the Ibero-American context. Ibero-America should be intended as a 'space' that goes beyond a mere geo-linguistic area, tracing cultural, socio-political and socioeconomic relationships, within it (Tejedor, Ventín, Cervi, Pulido, \& Tusa, 2020). Along the same lines, these authors have stressed the need to deepen on the knowledge of this field in the area. Based on this, the present study presents a diagnostic analysis of the consumption of information by university students in the field of communication.

Accordingly, our descriptive and exploratory research aims at understanding the informative habits of journalism students and their position towards fake news, answering the two following research questions:
RQ1: How do young journalism students inform themselves.

RQ2: How do they position themselves towards fake news?

\section{Theoretical Framework}

\subsection{Fake News}

'Fake news' in the media is not a new phenomenon. On the one hand, there is no consensus on the origin of it. Some scholars consider that disinformation started with the earliest writing systems (Tandoc, Lim, \& Ling, 2017), others (Posetti \& Matthews, 2018) recall that early record dates back to ancient Rome, when Octavian launched a smear campaign against Antony made of short slogans written upon coins, comparing it to a sort of archaic Tweets. Most observers (Molina, Sundar, Le, \& Lee, 2019), however, trace it back to World War II, specifically to the Russian word dezinformatsiya, used by Soviet planners in the 1950s to describe the dissemination (in the press, on the radio, etc.) of false reports intended to mislead public opinion.

On the other hand, there is a wide consensus that whereas the use of disinformation is not new, the digital revolution has greatly enhanced public vulnerability. In particular, in an informative scenario dominated by the emergence of content designed for rapid viralization (Romero-Rodríguez, de-Casas-Moreno, \& Torres-Toukoumidis, 2016), the risk of disinformation increases. In other words, what is new is the speed, scale and massive proliferation and consumption of false information, in the current context of the destabilization of the mainstream media (Cervi, 2019) and information disorder (Wardle \& Derakhshan, 2017).

In particular, as pointed out by Giglietto, Righetti, Rossi, and Marino (2020), two recent events-2016 Presidential elections in the US and Brexit referendum in UK-showed how the antagonist online participatory practices of sharing, collaborating and organizing collective actions, considered the prerogative of democratizing forces fighting established powers, proved to be just as effective in supporting the spread of extremisms, hate speech, violence and fake news.

Since then, 'fake news' has become a buzzword (Tandoc et al., 2017), thus, like other buzzwords, semantically confusing. Although since then there has been an explosion of both academic and journalistic work on this topic, defining 'fake news' is not an easy task.

Tandoc et al. (2017), analysing how the term has been used by scholars, reveal up to six types of definition: news satire, news parody, fabrication, manipulation, advertising, and propaganda. Earlier studies, in fact, have applied the term to define related but distinct types of content, such as news parodies or political satires (Blanco Alfonso et al., 2019), or to define information that adopted conventional news formats to 
make satirical commentary, as in the case of late-night TV shows. Other approaches pointed at tabloid journalism, that walked a fine line between reporting reality and making wild claims (Molina et al., 2019) and news propaganda (Pérez-Tornero, Tayie, Tejedor, \& Pulido, 2018). Currently the term is mostly used to generically describe false stories spreading on social media.

Acknowledging the complexities and ambiguity of the term, and stressing out the need for further definitory work, we understand 'fake news' within the broader phenomenon of disinformation, as a deliberate effort to mislead, deceive, or confuse an audience in order to promote their personal, religious, or ideological objectives (Cervi \& Carrillo-Andrade, 2019; Fetzer, 2004; Pérez-Tornero et al., 2018; Thompson, 2016; Turkle, 2015).

\subsection{Fake News, the Audience and Young People}

As previously mentioned, since 2016 there has been an explosion of academic work that fixes its subject matter using the terms 'fake news,' this topic of fake news has become one of the most talked about during Covid-19 lockdown, to the extent that the World Health Organization warned of the risk of the growth of the generation and circulation of this type of content.

This topic has received attention in a variety of fields, with scholars investigating the antecedents, characteristics, and consequences of its creation and dissemination. It is possible to divide these studies into two macro branches: Those who focus on the supply side, that is to say, primarily interested in the nature and construction of fake news, and those interested in the consumption side, geared at understanding why people consume, share and/or believe 'fake news.'

A recent research by Pennycook, Cannon, and Rand (2018), for example, warns of an 'illusory truth effect' linked to fake news headlines. The authors argue that social networks enhance the attraction and belief in this type of false content, while pointing out that the categorisation of this content as unreliable is not an effective solution to the problem of fake news. In this sense, they mention examples of implausible contents and stories labelled as controversial that reached important credibility rates among Internet users. Accordingly, the works of Marcom, Murdoch, and Caulfield (2017) and those of Peters, Tartari, Lotfinejad, Parneix, and Pittet (2018) and Guess, Nagler, and Tucker (2019) in the field of health, warn that in the current scenario, marked by fake news, even a correctly conducted investigation could be distorted to make people believe something is false.

Most of the works concentrating on the user side deal with how people assess the messages they receive and how they establish criteria of credibility. In this vein, Tandoc et al. (2018) discover that people rely on both their own judgment of the source and the message, and when this does not adequately provide a definitive answer, they turn to external resources to authen- ticate news items. Along the same lines, Samuel-Azran and Hayat (2019) have pointed out that the social link between the user who distributes the content and the users who receive it impacts on the effect of the perception of credibility with respect to the news source, as well as on the credibility conferred on the message received. In another study, Pennycook and Rand (2019) claim that users resort to analytical thinking to assess the plausibility of potential fake news headlines. Thus, the authors conclude that the vulnerability of citizens to fake news is more a result of the inertia of lazy thinking than of partisan bias.

As previously mentioned, numerous studies (Hargittai et al., 2010; Wineburg \& McGrew, 2016) have highlighted that young people, especially Generation Zers, are the most vulnerable to fake news.

Although there is no absolute consensus about the precise boundaries of Generation Z, most literature (Dimock, 2019) considers that it is composed of individuals born between the years 1996 and 2010. Their most important characteristic is that they are the first generation that has never known a world without the Internet. Their lives are moulded by the Internet, that has been converted in a natural part of their lives. In this vein, Marchi (2012) discusses how teenagers get informed about current events and why they prefer certain news formats to others. The results reveal changing ways news information is being accessed, new attitudes about what it means to be informed, and a youth preference for opinionated rather than objective news.

Generation Z will also be the most educated generation ever (Dimock, 2019). Notwithstanding, other studies (Chen, Sin, Theng, \& Lee, 2015) have proven that the acquisition of a high level of education for an individual does not mean that this individual will stop accessing and distributing fake news. Other resources are needed.

\subsection{Fake News, Future Journalists and Media Literacy}

Many works focusing on the susceptibility of users and the reason why people might fall for false news, make efforts to propose concrete initiatives able to provide citizens with the necessary tools and skills to protect themselves from this vulnerability. All these studies agree that media literacy is the key for providing Internet users with a set of skills and abilities that will enable them to navigate with confidence, criteria and ethical parameters in cyberspace.

From an institutional perspective, the European Union defines 'media literacy' as the "capacity to access, have a critical understanding of, and interact with the media" (European Political Strategy Centre, 2017) and defends that media literacy is more important than ever, mainly in relation to young people's poor ability to distinguish fake news from true news, to perceive the influence of algorithms on social networks or to recognize bots. Until now, the European Commission's efforts have focused on promoting and measuring those more 
technical skills (Durán-Becerra, 2016; Guess et al., 2019). UNESCO, on its side gives a special importance to the information within its proposed definition of 'media and information literacy' (UNESCO, 2013, 2018).

Media and information literacy share conceptual terrain and often overlap. Livingstone, Van Couvering, and Thumim (2008, p. 107) propose the following differentiation: "Media literacy sees media as a lens or window through which to view the world and express oneself, while information literacy sees information as a tool with which to act upon the world." We align with Pérez-Tornero and Varis' (2010) holistic approach, understanding media literacy as a concept embracing all the fields and all the competences related to media, that include news literacy.

Thus, news literacy can be defined a series of competences related to news, within the broader concept of media literacy. Malik, Cortesi, and Gasser (2013, pp. 8-9) propose a definition based on what it is meant to achieve: "An understanding of the role news plays in society; motivation to seek out news; the ability to find/identify/recognize news; the ability to critically evaluate news; the ability to create news."

Many studies stress out the benefit of media literacy (Spratt \& Agosto, 2017) and news literacy in providing people the competences to protect themselves against fake news (Vraga \& Tully, 2015; Vraga, Tully, Kotcher, Smithson, \& Broeckelman-Post, 2015). Lotero-Echeverri, Romero-Rodríguez, and Pérez-Rodríguez (2018), within the framework of a study that analyses the relationship between media competition and fake news, stress the importance of this set of skills in tackling the problem of disinformation in its different variants and contexts. Kahne and Bowyer (2016) demonstrate that young people who had exposure to media literacy education were significantly more likely than young people without such exposure to be guided by accuracy motivation when making judgments about controversial political claims; media literacy essentially helped young people to override the pull of prior beliefs, or directional motivation, in making such judgments. Media literacy training is also linked with increased perceptions of credibility and trust in news media and was found to help reduce perceptions of media bias (Vraga, Tully, Akin, \& Rojas, 2012).

Recent studies (Middaugh, 2019) focus specifically on critical skills as the most valuable resources to equip media users with. In an experiment related to coverage of biofuels, specific news media literacy training was found to reduce hostile interpretations of media, increase perceptions of news story credibility, and increase trust in the media generally and the news specifically (Vraga \& Tully, 2015, 2016).

As previously mentioned, Herrero-Diz et al. (2019) and Mendiguren et al. (2020) point out how journalism do not feel protected against 'fake news.' Accordingly, the works of Romero-Rodríguez and Aguaded (2016) have warned that the media literacy and information filtering capacities of journalism students in Latin
American countries denote a lack of critical and reflective analysis in relation to their deontological role in the processes of production of contents of a journalistic nature.

\section{Methods}

The research takes an exploratory perspective (Vilches, 2011), based on a hybrid methodology developed from a matrix survey of journalism students and a subsequent survey to find out the type of content they had received on their digital devices during the lockdown, especially focusing on the reception and sending of fake news. The survey samples have been selected for convenience and are composed of university students from the field of journalism at the Autonomous University of Barcelona (UAB). A total of 252 students participated in the surveys in 2019, comprising 143 women (57\%) and 109 men (43\%) aged 18-21. The survey conducted during the confinement in 2020 obtained 300 responses and was composed of $71 \%$ women and $29 \%$ men. The participants were informed of the study and their consent was requested to participate in it.

By focusing on a sample of students from a specific university, we do not intend to make any generalization, rather to offer an approximation. The UAB, thereby, has been selected for convenience (the researchers could conveniently have access to a representative sample of journalism for this educational centre) and because it is one of the better known and ranked universities at Spanish level in the Journalism field.

We complemented our research with students, with a focus group of teachers ( $n=6)$, from the same university and department, selected for being responsible of teaching different disciplines around Multimedia Journalism. In this article, they are identified as Professor 1, Professor 2 and, consecutively, up to 6 . The results of the focus group allow to assume a more qualitative perspective in the reading and interpretation of the students' answers. In order to further explore the information consumption and the position of journalism students towards fake news, the proposed method should be scaled to a broader sample, as well as to other cases.

The research combines both quantitative and qualitative data. Both the survey and the focus group have been designed based on a structured form of questions, both closed and open, mostly designed to encourage qualitative reflection.

The 2019 questionnaire, validated by a panel of experts $(n=10)$ in journalism, is composed of 22 open and closed questions about the identification and attitudes towards fake news, summarized in Table 1.

In addition, as an experimental manner, questions have been incorporated with examples of news that respondents should identify as true or fake news (see Figure 1).

The 2020 survey was not identical to the previous one, mainly focusing about disinformation during Covid-19 crisis, however it shared five questions with the 
Table 1. Thematic variables.

\begin{tabular}{|c|c|c|}
\hline Research questions & Variables & Categories of analysis \\
\hline \multirow{3}{*}{$\begin{array}{l}\text { How do journalism students } \\
\text { get information? }\end{array}$} & Information consumption & $\begin{array}{l}\text { Habits of access and consumption of informative } \\
\text { content. Frequency, sources and objectives }\end{array}$ \\
\hline & Sources of information & Identification of information sources typologies \\
\hline & $\begin{array}{l}\text { Information validation and } \\
\text { contrasting }\end{array}$ & $\begin{array}{l}\text { Routines of verification, contrast and validation of } \\
\text { the consulted content }\end{array}$ \\
\hline \multirow{5}{*}{$\begin{array}{l}\text { What is their attitude } \\
\text { towards fake news? }\end{array}$} & Authorship of the fake news & Subjects responsible for the creation of false news \\
\hline & Reason to create fake news & Reflection on the reasons of their production \\
\hline & Audience & $\begin{array}{l}\text { Typology of profiles and degrees of vulnerability to fake } \\
\text { news. Analysis of the intergenerational component }\end{array}$ \\
\hline & Methods to spot fake news & Identifying features/traits of fake news \\
\hline & Importance and reach & $\begin{array}{l}\text { Assessment of the seriousness and repercussions of } \\
\text { the spread of false news }\end{array}$ \\
\hline
\end{tabular}

previous survey (see Table 1), that have been taken into consideration in order to complement and enrich 2019's study, addressing our RQ1.

\section{Results}

\subsection{Information Consumption by Young Journalism Students}

The first part of the 2019 survey deals with young people's information habits and relationship with different sources. To begin with, $90 \%$ of the respondents answered that they do use social networks for getting information. However, when asked about their favourite sources of information, more than $67 \%$ prefer online newspapers.

They consume updates on Instagram or Facebook from media accounts such as Código Nuevo, EI País, VICE, just as they follow posts from friends or family, but they do not deliberately access them to be informed, they follow certain social accounts of online newspapers that sporadically feed them with information pills.

When it comes to topic that interest the young journalism students, $89 \%$ of respondents identify politics as the top thematic issue in their access to cyberspace platforms, with events (at 60\%) and sports (at 23\%) ranking second and third, respectively.

When it comes to one of the fundamental practices of the profession, contrasting information, the majority (77.1\%) assures that they do, although only $43.3 \%$ say that they do so to verify the first information received; $30.6 \%$ say that they consult other sources to expand the information with more data, and $3.2 \%$ cite other reasons. Among those who assume that they are not in the habit of contrasting the information received, $12.3 \%$ say that they usually trust the first medium through which they receive the news, $7.5 \%$ say that they do not have time to verify the information, and $3.2 \%$ cite other reasons.
News A (true)

\begin{tabular}{|c|c|}
\hline & SUR \\
\hline Málaga Andalucía España Mundo Economía Málaga CF Unicaja CB Deportes
\end{tabular}

\section{Detienen a un hombre por llamar 2.600 veces a una compañía telefónica para no estar solo}

$$
\begin{aligned}
& \text { "Soy soltero, lo hice para distraerme de mi soledad", dijo a los } \\
& \text { agentes tras su detención } \\
& \begin{array}{l}
\text { EFE } \\
\text { Mércoles, } 30 \text { enero 2008, 13:28 }
\end{array}
\end{aligned}
$$

News B (false)

\section{mediterráneoDIGITAL

$$
\text { POLITICAMENTE INCORRECTO }
$$

FA ESPAAA OPNION SUCESOS IDENTTARIOS SOCLEDAD FNANZAS GENTEYTV HISTORIA FEMNISMO MO SPOR

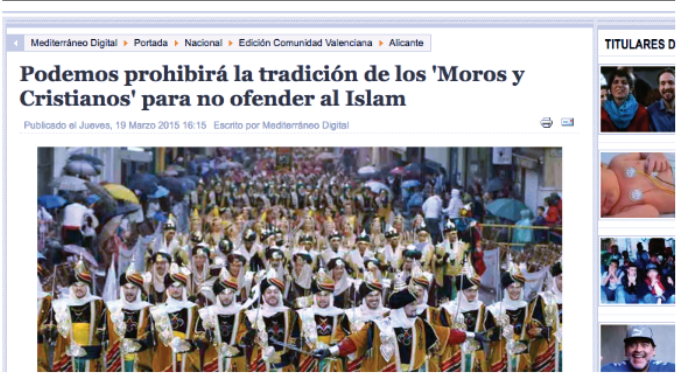

Figure 1. Example of question based on a case. Source: Authors. 
Besides the habit of verifying or not the information, the students were also asked if they usually comment or discuss the news with their personal environment, as it can be seen in Figure 2. In this line, 50\% assure that sometimes a week they discuss with their family or friends about this type of content; while $31 \%$ indicate that they do it daily.

Teachers, on their side, doubt about the quality of the debate they generate. According to Professor 3:

Most of them stay with the headline, this is not enough to have a deeper debate. Such an epidermal reading of information does not allow a subsequent debate to be generated when questioning information, let alone being able to glimpse the certainty of whether an item of information is false, real or true.

\subsection{Journalism Students' Position towards Fake News}

When asked how they would define so-called fake news, the most frequent responses were 'fake news,' 'fake fact' or similar, clearly associated with a literal translation of the English expression. But as this is an open question, we can gather a series of concepts and ideas, which are part of the conception of future journalists with the fake news. In Table 2, we present some of these recurrent ideas, which are basically associated with three elements or categories: the sender (his interests or professional practice), the message (its characteristics) and the objective (or intentionality) of the information.

There is a predominance of ideas associated with 'cheating,' 'manipulating,' 'confusing,' 'benefiting,' 'harming,' i.e., mainly focused on aims or objectives that are incompatible with the ethics and professional deontology of journalism.

When it comes to the topic mostly affected by fake news, Figure 3 shows that Culture, Politics and Events are the most quoted.

During Covid-19 pandemic, according to the respondents of the 2020 survey, fake news accounted for $4.5 \%$ of all the content received. Although they were not the most recurrent, $91.1 \%$ of the students acknowledge that they received this type of content, especially during the quarantine period.
Although most experts recognize that most of fake news are circulated for political reasons, students in the 2019 survey do not seem to be aware of this, precisely the politicians are in third place, they consider that the Internet users are the main distributors of fake news (see Figure 4).

As for the digital platforms on which they believe in which more fake news were circulating during the 2020 pandemic, more than half of the students indicated Facebook as the first (28.6\%) or second choice (26.2\%) closely followed by Twitter ( $24.6 \%$ and $23 \%$, respectively). At the other end of the scale, online newspapers were considered to have the least amount of fake news (30\% of those interviewed placed them at the top of the scale).

As Professor 4 states: "Social networks are another means to manipulate people and show or facilitate the information that interests them at a political or economic level...they do not have a critical vision to listen to other points of view." Therefore, teachers consider critical skills in students essential, especially media literacy. In spite of being journalism students, they "do not consult other sources or evaluate the journalist's information." The personification of information influences the belief of truth: "[Students] believe it and from there they don't move, like extremist positions, as this person said I don't believe the version that you say." And highlighting the phenomenon of echo chambers, Professor 4 explains a recent conversation with an Al specialist: "I was saying that we like to be given our ears, we believe the news we like." Professor 5 points out as an example of this in the political arena the case of Brexit in 2016 and the US elections in Trump. Professor 4 concludes by stressing the importance of democratic journalism, quoting the recognized journalist Martín Caparrós, who says: "In journalism it is not only necessary to tell people what they have the right to hear, but also to report what they do not want to hear and know."

Regarding the age groups that, in their opinion, contributed most to the misinformation, the students indicated: adults (43.3\%), almost tied with adolescents $(42.9 \%)$, and followed more closely by the elderly (12.7\%) and children (1.2\%). And on the motivations for contributing to disinformation, $24.6 \%$ consider that ideological interests predominate, $11.1 \%$ highlight economic

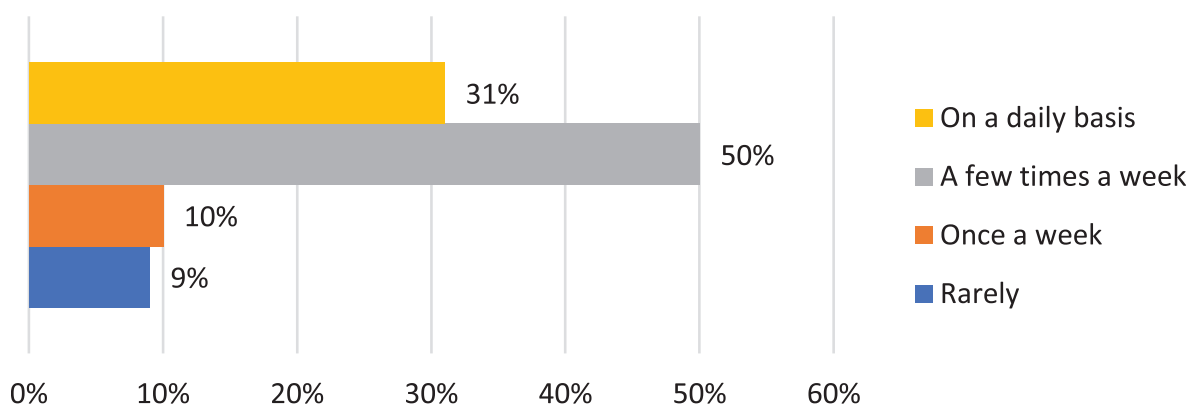

Figure 2. How often do you discuss the news with your family and friends? 
Table 2. Concept and ideas about fake news.

\begin{tabular}{|c|c|c|}
\hline Sender & Message & Intentionality \\
\hline $\begin{array}{l}\text { "News published by } \\
\text { sensationalist media..." }\end{array}$ & $\begin{array}{l}\text { "...news with false data or completely } \\
\text { invented..." }\end{array}$ & "...to attract the attention of the audience." \\
\hline $\begin{array}{l}\text { "...might be influenced by } \\
\text { interests unrelated to the } \\
\text { transmission of events." }\end{array}$ & $\begin{array}{l}\text { "...news based on totally or partially } \\
\text { fictitious facts..." }\end{array}$ & $\begin{array}{l}\text { “...in order to make believe something or } \\
\text { create an opinion about some subject } \\
\text { or person." }\end{array}$ \\
\hline $\begin{array}{l}\text { "News not based on solid } \\
\text { arguments or reliable } \\
\text { sources..." }\end{array}$ & $\begin{array}{l}\text { "...news in which is included untrue } \\
\text { information or part of it is hidden..." }\end{array}$ & $\begin{array}{l}\text { "...to damage another person's image, to } \\
\text { see the effect it has and for the author's } \\
\text { own interest..." }\end{array}$ \\
\hline $\begin{array}{l}\text { "...coming from doubtful } \\
\text { sources..." }\end{array}$ & $\begin{array}{l}\text { "...fake news that can be understood } \\
\text { as true." }\end{array}$ & “...seeks to harm someone or a collective." \\
\hline $\begin{array}{l}\text { "...with interests unrelated to } \\
\text { veracity, ethics and civic } \\
\text { responsibility..." }\end{array}$ & $\begin{array}{l}\text { "...false information spread by error } \\
\text { or by lack of foundation and } \\
\text { investigation." }\end{array}$ & “...are intended to create a social alarm.” \\
\hline $\begin{array}{l}\text { “...made up by unreliable } \\
\text { media..." }\end{array}$ & $\begin{array}{l}\text { "News that have a high percentage } \\
\text { of falseness..." }\end{array}$ & $\begin{array}{l}\text { "...the intention to deceive the reader } \\
\text { about an event." }\end{array}$ \\
\hline \multirow[t]{6}{*}{$\begin{array}{l}\text { "...often published by the } \\
\text { country's leading newspapers } \\
\text { and television stations." }\end{array}$} & $\begin{array}{l}\text { "...tries to appear of being true but } \\
\text { the information it offers cannot be } \\
\text { contrasted." }\end{array}$ & $\begin{array}{l}\text { "...whose author has no intention of } \\
\text { informing, but of gaining an easy click or } \\
\text { influencing the public." }\end{array}$ \\
\hline & $\begin{array}{l}\text { "It's often alarmist, ambiguous, } \\
\text { unrealistic and even ridiculous news." }\end{array}$ & $\begin{array}{l}\text { "...created with the will to influence the } \\
\text { reader by manipulating information." }\end{array}$ \\
\hline & $\begin{array}{l}\text { "...nobody knows where it comes } \\
\text { from (source), everybody believes it } \\
\text { and shares it very quickly." }\end{array}$ & $\begin{array}{l}\text { “...wants to spread a rumor of false news } \\
\text { to confuse people..." }\end{array}$ \\
\hline & $\begin{array}{l}\text { "They decontextualize an event, } \\
\text { make it seem more alarmist." }\end{array}$ & $\begin{array}{l}\text { "...with the aim of confusing society or } \\
\text { supporting a specific ideology." }\end{array}$ \\
\hline & & "...in order to satisfy or attack an ideology." \\
\hline & & “...is intended to disinform." \\
\hline
\end{tabular}

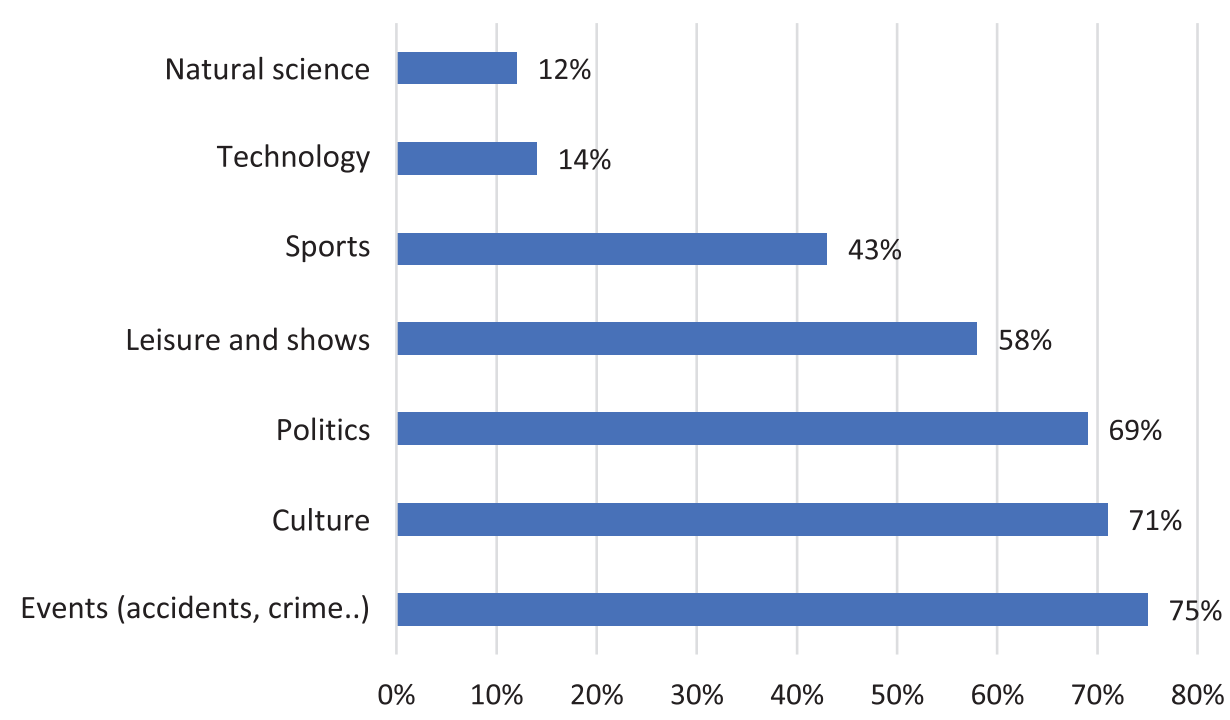

Figure 3. Which is the topic mostly affected by fake news? 
$\square$ First place $\square$ Second place $\square$ Third place $\square$ Fourth place $\square$ Fifth place $\square$ Sixth place

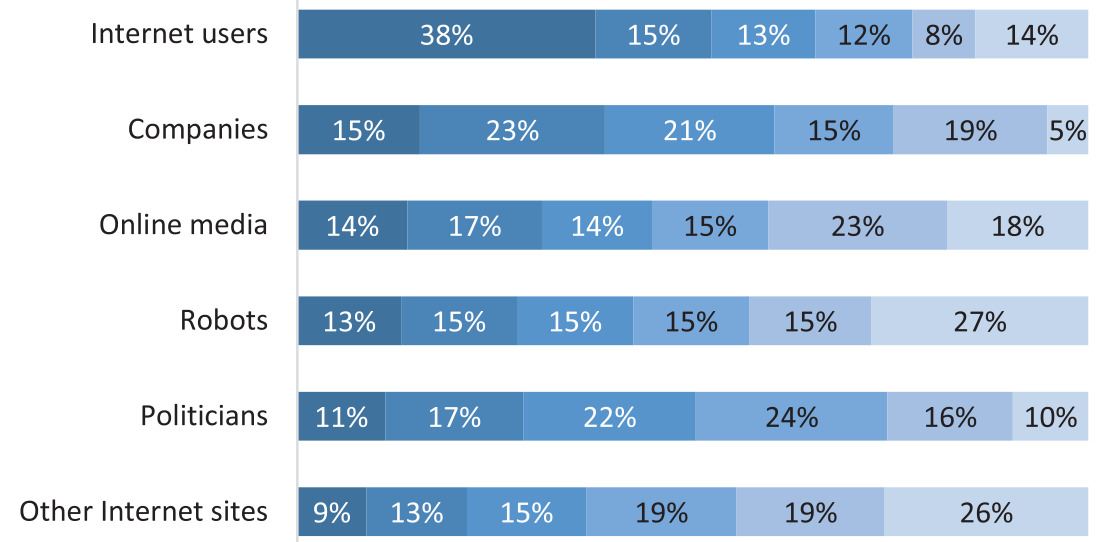

Figure 4. Who/which is the main source of fake news?

interests, but the majority consider that both ideological and economic interests motivate the creation and dissemination of false information in the same way. Regarding the ideology of the users who disseminate the most fake news, it should be noted that the vast majority of students agree that it is the right wing that shares the falsest information.

According to Professor 4, this response from the students "is not ideologically motivated, but rather in line with society." And as Professor 3 rightly comments:

It makes no sense to ask and consider the survey sample if they think that the fake news is mostly distributed by the left, the right, etc....The students in the survey show in their response that they are starting from a previous mistake, a product of ideological and cultural warfare, which is to assume that the falsified news is the product of a specific political ideology, without contrasting.

On the other hand, they were also asked about their own behaviour as Internet users, and whether they share or have shared fake news for any reason. The vast majority of the sample shared fake news, either deliberately or by mistake. Less than half (44.1\%) said they had never shared a piece of fake news. Among the majority who do admit to having done so, they justify themselves on different grounds as shown in Figure 5.

The data leads us to question whether journalism students really know how to recognize fake news. Likewise,

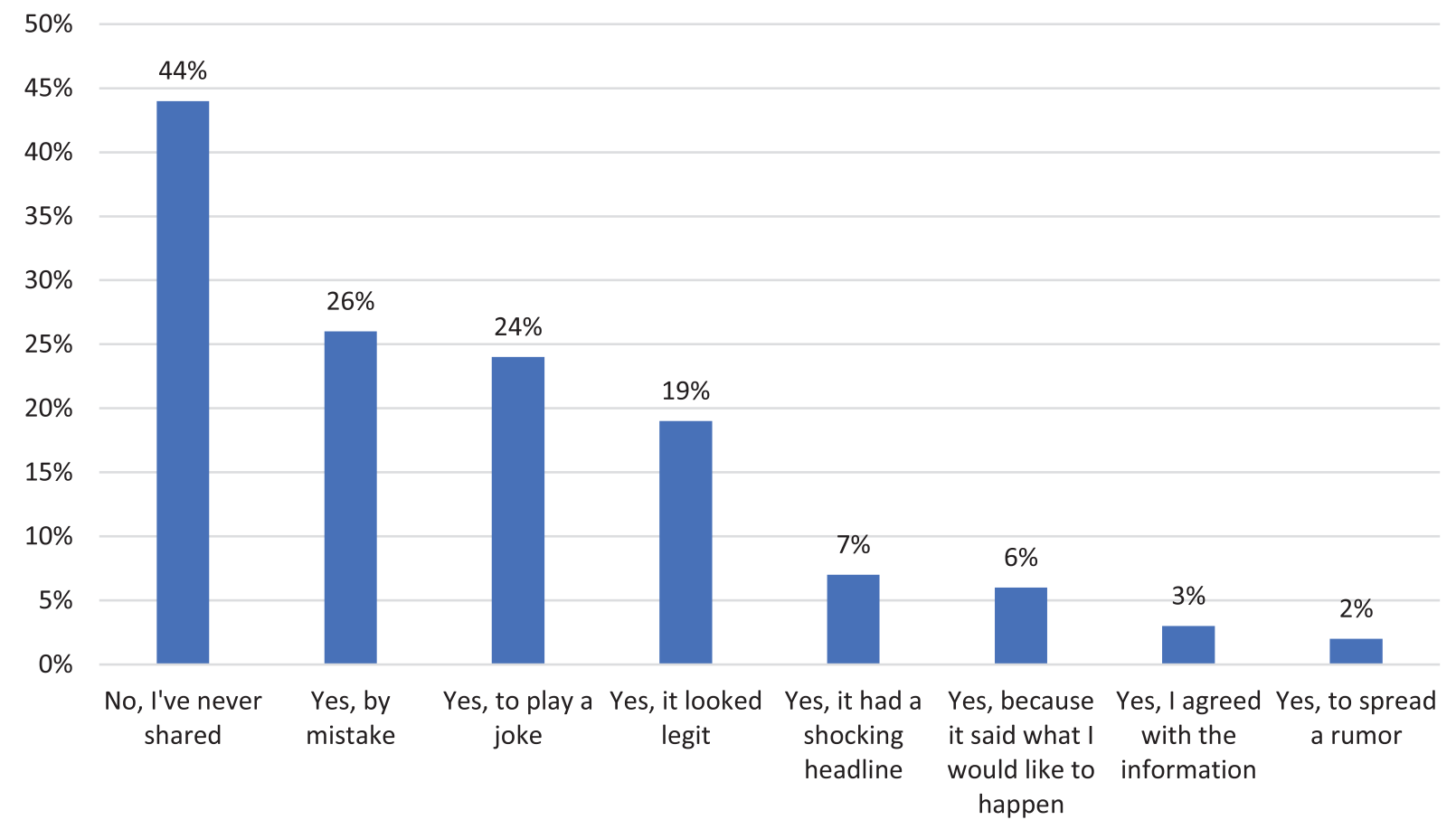

Figure 5. Have you ever shared fake news? 
taking up the definitions above (Table 2), it is striking that some students connect fake news with the perception of news that cannot be contrasted and that is credible to most of the public.

Teachers perspective is particularly interesting: they insist that: "When it comes to fake news students are as helpless as everyone else" (Professor 2), however they recognized, as expressed by Professor 1, that "by end the semester they learn that it is necessary to verify, contextualize and check more than one source."

In this sense, when asked if they know when they are reading fake news, just over half $(51.2 \%)$ answered 'sometimes.' $48 \%$ said they know 'almost always' when they read fake news, and $0.8 \%$ said they 'never' know. But no student claimed to 'always' know when they have false information in front of them. These answers somehow clash with another similar question. When asked if they think they know how to distinguish fake news from true information, less than half of the students (46.4\%) said they think they know; $6.8 \%$ think they do not know how to make this distinction, and another $46.8 \%$ do not know what to answer. In order to contrast the self-perceptive information of whether they were able to detect fake news from true ones, a small evaluation test was elaborated, following the methodology of the media competence tests and $82 \%$ of the students correctly identified the fake news.

Students were also asked about the main elements or features that, in their opinion, allow the reader to detect fake news. As shown in Figure 6 most of them point to the headline style and the sources.

In conclusion, to answer RQ1, students consume information on social networks. Nonetheless, their main source of information, are online mainstream media and traditional media (TV or print). Interestingly, students consider that it is precisely social networks that spread the most fake news: firstly, Facebook, followed in second place by Twitter and in third place by Instagram. While cybermedia or other Internet sites are in fourth and fifth place respectively. However, despite identify- ing these networks as the most active in disseminating fake news, they are the platforms most consulted in their information habits.

To answer RQ2, students consider that fake news are: a) False news published by a specific issuer; $b$ ) news with untruthful data, therefore, the message is wrong; and c) carrying an intentionality behind their dissemination. In this case, they think that it is mainly generated from political actors. They consider that the profile of the disseminator of false news is a user of social networks, mainly adolescent or adult. In addition, most students know that fake news is spread because of ideological and economic interests. Along these lines, students consider that politics is the subject that generates the most of false news, an aspect that is surely influenced by the country's political instability and the daily lives of young people. In relation to this, the students assure that those who spread the most fake news are the centre-right users.

Furthermore, no student in the sample knows for sure whether he or she is reading a false story. In this sense, a little more than half recognize detecting them only sometimes. This conclusion was reached even though they answered the evaluation question about detecting a fake news item correctly. Most students admit to sharing fake news (a quarter were by mistake or legitimate appearance).

In conclusion, it is necessary to take up the opinion of Professor 3, who states that we are witnessing "an infantilization of society and a cultural war for de-democratization." According to the interviewee fake news are nothing new, "All the reception studies and Walter Lippmann's theorization on public opinion has already warned us, but the consequences in the society of fake news are going to be catastrophic."

\section{Discussion and Conclusions}

Besides the geographical and sample limitations, our findings perfectly align with other studies realized in Spain (Herrero-Diz et al., 2019; Mendiguren et al., 2020),
Headlines that are too alarmist, ridiculous or unlikely

The medium in which it is published

Common sense/logic/coordination

The unreality of the content

Sources of information are cited

Author checks/verifies information in the text

$$
\begin{aligned}
& \text { Other reasons } \\
& \text { I don't know }
\end{aligned}
$$

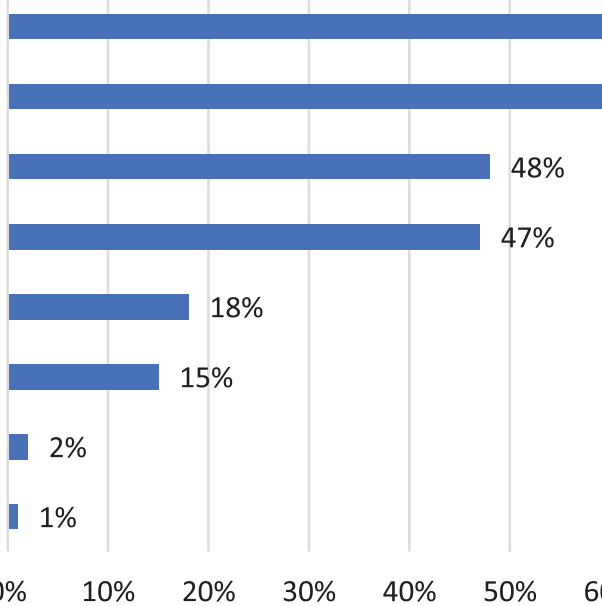

Figure 6. How can you spot fake news? 
allowing to argue that certain trends are retrievable, at least at Spanish level: Journalism students get informed through social media, even if when looking for information they rely more online mainstream media. As for 'fake news,' they are well informed about what these are, they are concerned about this phenomenon, but they do not feel to have the necessary ability to spot one.

Our results also align with the findings on other studies in other contexts (Bhaskaran et al., 2019). To confirm this assumption, more meticulous comparative research is needed, not to overstate what could be context-specific and to allow some extent of generalization. Thereby, comparative and international research, besides assessing their perceptions, should go further into the specific assessment of the critical abilities of the students to spot fake news.

However, our results stress out the need to foster media literacy skills. Actions that encourage critical thinking must be implemented constantly. Education at the general level has an undisputed role in ensuring a medialiterate society. This milestone encompasses not only digital competencies and technical skills, but also the importance of critical thinking in the face of increasingly changing information environments. In addition, issues such as $\mathrm{Al}$, content creation robots and newsroom automation are taking a predominant role in communication.

In particular, fake news represent a threat not only for all the citizens, but for the future of journalism itself. Specifically, as the former editor of The Guardian, Alan Rusbridger (2018, p. 4), observes:

Journalism is facing an existential economic threat in the form of a tumultuous recalibration of our place in the world. And on both sides of an increasingly scratchy debate about media, politics, and democracy, there is a hesitancy about whether there is any longer a common idea of what journalism is and why it matters.

Journalism Studies need to adapt accordingly and so Journalism Faculties and Schools. As Silvio Waisbord (2018) notes, it is necessary to weave the study of journalism with the rapidly, constantly changing communication ecology.

Various studies (Cervi, Pérez-Tornero, \& Tejedor, 2020; Cervi, Simelio, \& Tejedor Calvo, 2020) have already pinpointed that most Journalism School's educational programs are not ready to adapt to the important structural changes that the profession have undergone in recent years. Others (Waisbord, 2018) have highlighted the need to develop transversal actions for instructing both university professors and students in media competences to face an ecosystem dominated by fake news and disinformation. Thereby, our findings, together with the positive assessment of media literacy initiative (Vraga \& Tully, 2015; Vraga et al., 2015), allow to suggest the need to reform journalism curricula focusing on the promotion of media literacy among students (Tejedor \&
Cervi, 2017). In particular, news literacy (Spratt \& Agosto, 2017), understood of a sub-branch of media literacy, is seen as a crucial competence for journalism students, but also as a necessary tool to recover the value of professional journalism and its foundational values, fundamental for the development and maintenance of a healthy public sphere.

\section{Conflict of Interests}

The authors declare no conflict of interests.

\section{References}

Bhaskaran, H., Mishra, H., \& Nair, P. (2019). Journalism education in post-truth era: Pedagogical approaches based on Indian journalism students' perception of fake news. Journalism \& Mass Communication Educator, 74(2), 158-170. https://doi.org/10.1177\% 2F1077695819830034

Blanco Alfonso, I., García Galera, C., \& Tejedor Calvo, S. (2019). El impacto de las fake news en la investigación en Ciencias Sociales: Revisión bibliográfica sistematizada [The impact of fake news on Social Science Research: Systematized bibliographic review]. Historia y Comunicación Social, 24(2), 449-469. https:// doi.org/10.5209/hics.66290

Cervi, L. (2019). Citizen journalism and user generated content in mainstream media: New dialogic form of communication, user-engagemente technique or free labor exploration? Revista de Comunicação Dialógica, 1, 120-141. https://doi.org/10.12957/rcd. 2019.41871

Cervi, L., \& Carrillo-Andrade, A. (2019). Post-truth and disinformation: Using discourse analysis to understand the creation of emotional and rival narratives in Brexit. ComHumanitas: Revista Científica de Comunicación, 10, 125-149. https://doi.org/10.31207/rch. v10i2.207

Cervi, L., Pérez-Tornero, J. M., \& Tejedor, S. (2020). The challenge of teaching mobile journalism through MOOCs: A case study. Sustainability, 12(13). https:// doi.org/10.3390/su12135307

Cervi, L., Simelio, N., \& Tejedor Calvo, S. (2020). Analysis of journalism and communication studies in Europe's top ranked universities: Competencies, aims and courses. Journalism Practice. https://doi. org/10.1080/17512786.2020.1762505

Chen, X., Sin, S. C. J., Theng, Y. L., \& Lee, C. S. (2015). Why students share misinformation on social media: Motivation, gender, and study-level differences. Journal of Academic Librarianship, 41(5), 583-592. https:// doi.org/10.1016/j.acalib.2015.07.003

Dimock, M. (2019, January 17). Defining generations: Where Millennials end and Generation $Z$ begins. Pew Research Center. Retrieved from https://www. pewresearch.org/fact-tank/2019/01/17/wheremillennials-end-and-generation-z-begins 
Durán-Becerra, T. (2016). AMI en Latinoamérica: Aproximación, análisis y propuesta de medición sobre el contexto de la Alfabetización Mediática e Informacional en América Latina [AMI in Latin America. Aproximation, analysis and measurement proposal on the context of media and information literacy in Latin America] (Doctoral dissertation). Autonomous University of Barcelona, Barcelina, Spain. Retrieved from https://ddd.uab.cat/record/173980

European Political Strategy Centre. (2017). 10 Trends transforming education as we know it. European Political Strategy Centre. Retrieved from https:// op.europa.eu/en/publication-detail/-/publication/ 227c6186-10d0-11ea-8c1f-01aa75ed71a1

Fetzer, J. H. (2004). Disinformation: The use of false information. Minds and Machines, 14, 231-240. https:// doi.org/10.1023/B:MIND.0000021683.28604.5b

Fletcher, R., Cornia, A., Graves, L., \& Rasmus, K. (2018). Measuring the reach of fake news and online disinformation in Europe. Oxford: Reuters Institute for the Study of Journalism.

Giglietto, F., Righetti, N., Rossi, L., \& Marino, G. (2020). It takes a village to manipulate the media: Coordinated link sharing behavior during 2018 and 2019 Italian elections. Information, Communication \& Society, 23(6), 867-891. https://doi.org/10.1080/1369118X. 2020.1739732

Guess, A., Nagler, J., \& Tucker, J. (2019). Less than you think: Prevalence and predictors of fake news dissemination on Facebook. Science Advances, 5(1). https:// doi.org/10.1126/sciadv.aau4586

Hargittai, E., Fullerton, L., Menchen-Trevino, E., \& Thomas, K. (2010). Trust online: Young adults' evaluation of web content. International Journal of Communication, 4, 468-494.

Herrero-Diz, P., Conde-Jiménez, J., Tapia-Frade, A., \& Varona-Aramburu, D. (2019). The credibility of online news: An evaluation of the information by university students. Culture and Education, 31(2), 407-435. https://doi.org/10.1080/11356405.2019.1601937

Ireland, S. (2018). Fake news alerts: Teaching news literacy skills in a meme world. The Reference Librarian, 59(3), 1-7. https://doi.org/10.1080/02763877.2018. 1463890

Jang, S. M., \& Kim, J. K. (2018). Third person effects of fake news: Fake news regulation and media literacy interventions. Computers in Human Behavior, 80, 295-302. https://doi.org/10.1016/j.chb.2017.11. 034

Kahne, J., \& Bowyer, B. (2016). Educating for democracy in a partisan age: Confronting the challenges of motivated reasoning and misinformation. American Educational Research Journal, 54(1), 3-34. https:// doi.org/10.3102\%2F0002831216679817

Livingstone, S., Van Couvering, E., \& Thumim, N. (2008). Converging traditions of research on media and information literacies: Disciplinary, critical, and methodological issues. In J. Coiro, M. Knobel, C. Lankshear,
\& D. Leu (Eds.), Handbook of research on new literacies (pp. 103-132). New York, NY: Lawrence Erlbaum Associates.

Lotero-Echeverri, G., Romero-Rodríguez, L. M., \& PérezRodríguez, M. A. (2018). Fact-checking vs. Fake news: Periodismo de confirmación como componente de la competencia mediática contra la desinformación [Fact-checking vs. fake news: confirmation journalism as a tool of media literacy against misinformation]. Index Comunicación, 8(2), 295-316.

Love, R. (2007). Before Jon Stewart. Columbia Journalism Review, 45(6), 33-37.

Malik, M., Cortesi, S. C., \& Gasser, U. (2013). The challenges of defining 'news literacy.' Berkman Center Research Publication. http://dx.doi.org/10.2139/ ssrn. 2342313

Marchi, R. (2012). With Facebook, blogs, and fake news, teens reject journalistic "objectivity." Journal of Communication Inquiry, 36(3) 246-262.

Marcom, A., Murdoch, B., \& Caulfield, T. (2017). Fake news portrayals of stem cells and stem cell research. Regenerative Medicine, 12(7), 765-775. https://doi. org/10.2217/rme-2017-0060

Mendiguren, T., Pérez Dasilva, J., \& Meso Ayerdi, K. (2020). Actitud ante las fake news: Estudio del caso de los estudiantes de la Universidad Del País Vasco [Facing fake news: The case of the students of the University of the Basque Country]. Revista de Comunicación, 19(1), 171-184. https://doi.org/10.26441/ RC19.1-2020-A10

Middaugh, E. (2019). More than just facts: Promoting civic media literacy in the era of outrage. Peabody Journal of Education, 94(1), 17-31. https://doi.org/ 10.1080/0161956X.2019.1553582

Molina, M. D., Sundar, S. S., Le, T., \& Lee, D. (2019). 'Fake news' is not simply false information: A concept explication and taxonomy of online content. The American Behavioral Scientist. https://doi.org/10.1177\% 2F0002764219878224

Musgrove, A., Powers, J., Rebar, L., \& Musgrove, G. (2018). Real or fake? Resources for teaching college students how to identify fake news. College \& Undergraduate Libraries, 25(3), 243-260. https://doi.org/ 10.1080/10691316.2018.1480444

Pennycook, G., Cannon, T. D., \& Rand, D. G. (2018). Prior exposure increases perceived accuracy of fake news. Journal of Experimental Psychology: General, 147(12), 1865-1880.

Pennycook, G., \& Rand, D. G. (2019). Lazy, not biased: Susceptibility to partisan fake news is better explained by lack of reasoning than by motivated reasoning. Cognition, 188, 39-50, https://doi.org/ 10.1016/j.cognition.2018.06.011

Pérez-Tornero, J. M., Tayie, S., Tejedor, S., \& Pulido, C. (2018). ¿Cómo afrontar las noticias falseadas mediante la alfabetización periodística? Estado de la cuestión [How to confront fake news through news literacy? State of the art]. Doxa Comunicación: 
Revista Interdisciplinar de Estudios de Comunicación y Ciencias Sociales, 26, 211-235.

Pérez-Tornero, J. M., \& Varis, T. (2010). Media literacy and new humanism. Moscow: UNESCO Institute for Information Technologies in Education.

Peters, A., Tartari, E., Lotfinejad, N., Parneix, P., \& Pittet, D. (2018). Fighting the good fight: The fallout of fake news in infection prevention and why context matters. Journal of Hospital Infection, 100(4), 365-370. https://doi.org/10.1016/j.jhin.2018.08.001

Posetti, J., \& Matthews, A. (2018). A short guide to the history of 'fake news' and disinformation. Washington, DC: International centre for Journalists. Retrieved from https://www.icfj.org/sites/default/files/201807/A\%20Short\%20Guide\%20to\%20History\%20of\% 20Fake\%20News\%20and\%20Disinformation_ICFJ\% 20Final.pdf

Romero-Rodríguez, L. M., \& Aguaded, I. (2016). Consumo informativo y competencias digitales de estudiantes de periodismo de Colombia, Perú y Venezuela [Consumption of information and digital competencies of journalism students from Colombia, Peru and Venezuela]. Convergencia: Revista de Ciencias Sociales, 23(70), 35-57.

Romero-Rodríguez, L. M., de-Casas-Moreno, P., \& TorresToukoumidis, A. (2016). Dimensiones e indicadores de la calidad informativa en los medios digitales [Dimensions and indicators of informative quality in digital media]. Comunicar, 24(49), 91-100. https:// doi.org/10.3916/C49-2016-09

Rusbridger, A. (2018, August 31). Who broke the news? The Guardian. Retrieved from https://www. theguardian.com/news/2018/aug/31/alanrusbridger-who-broke-the-news

Samuel-Azran, T., \& Hayat, T. (2019). Online news recommendations credibility: The tie is mightier than the source. Comunicar, 60, 71-80. https://doi.org/ 10.3916/C60-2019-07

Southwell, B., Thorson, E., \& Sheble, L. (Eds.). (2018). Misinformation and mass audiences. Austin, TX: University of Texas.

Spratt, H. E., \& Agosto, D. (2017). Fighting fake news because we all deserve the truth: Programming idea for teaching teens media literacy. Young Adult Library Services, 15(4), 17-21.

Tally, R. (2011). I am the mainstream media (and so can you!). In A. Amarasingam (Ed.), The Stewart/Colbert effect: Essays on the real impacts of fake news (pp. 149-163). Jefferson, NC: McFarland.

Tandoc, E. C., Lim, Z. W., \& Ling, R. (2017). Defining 'fake news': A typology of scholarly definitions. Digital Journalism, 6(2), 137-153. https://doi.org/10.1080/ 21670811.2017.1360143

Tandoc, E. C., Ling, R., Westlund, O., Duffy, A., Goh, D., \& Zheng Wei, L. (2018). Audiences' acts of authentication in the age of fake news: A conceptual framework. New Media \& Society, 20(8), 2745-2763. https://doi. org/10.1177/1461444817731756
Tejedor, S., \& Cervi, L. (2017). Análisis de los estudios de Periodismo y Comunicación en las principales universidades del mundo: Competencias, objetivos $y$ asignaturas [Analysis of the journalism and communication degree programmes of the world's top-ranked universities: Competences, objectives and subjects]. Revista Latina de Comunicación Social, 72, 1626-1647. http://dx.doi.org/10.4185/ RLCS-2017-1238

Tejedor, S., Ventín, A., Cervi, L., Pulido, C., \& Tusa, F. (2020). Native media and business models: Comparative study of 14 successful experiences in Latin America. Media and Communication, 8(2), 146-158. http:// dx.doi.org/10.17645/mac.v8i2.2712

Thompson, M. (2016). Enough said: What's gone wrong with the language of politics? London: The Bodley Head.

Toffler, A. (1970). Future shock. New York, NY: Random House.

Turkle, S. (2015). Reclaiming conversation: The power of talk in a digital age. New York, NY: Penguin Press.

UNESCO. (2013). Global media and information literacy assessment framework: Country readiness and competencies. Paris: UNESCO Communication and Information Sector. Retrieved from https://unesdoc. unesco.org/ark:/48223/pf0000224655

UNESCO. (2018). Journalism, fake news, and disinformation. Paris: UNESCO Communication and Information Sector. Retrieved from https://en.unesco.org/ sites/default/files/brochure_-_journalism_fake_ news_and_disinformation.pdf

Vilches, L. (2011). La investigación en comunicación: Métodos y técnicas en la era digital [Communication research: Methods and techniques in the digital age]. Barcelona: Gedisa.

Vosoughi, S., Roy, D., \& Aral, S. (2018). The spread of true and false news online. Science, 359(6380), 1146-1151. https://doi.org/10.1126/sciencie. aap9559

Vraga, E. K., \& Tully, M. (2015). Effectiveness of a nonclassroom news media literacy intervention among different undergraduate populations. Journalism \& Mass Communication Educator, 71(4), 440-452. https://doi.org/10.1177/1077695815623399

Vraga, E. K., \& Tully, M. (2016). Effective messaging to communicate news media literacy concepts to diverse publics. Communication and the Public, 1(3), 305-322. https://doi.org/10.1177\%2F2057 047316670409

Vraga, E. K., Tully, M., Akin, M., \& Rojas, H. (2012). Modifying perceptions of hostility and credibility of news coverage of an environmental controversy through media literacy. Journalism, 13(7), 942-959. https:// doi.org/10.1177\%2F1464884912455906

Vraga, E. K., Tully, M., Kotcher, J. E., Smithson, A., \& Broeckelman-Post, M. (2015). A multi-dimensional approach to measuring news media literacy. Journal of Media Literacy Education, 7(3), 41-53. 
Waisbord, S. (2018). Truth is what happens to news. Journalism Studies, 19(13), 1866-1878. https://doi.org/ 10.1080/1461670X.2018.1492881

Wardle, C., \& Derakhshan, H. (2017). Information disorder: Toward an interdisciplinary framework for research and policymaking. Strasbourg: Council of Europe.

Wineburg, S., \& McGrew, S. (2016). Why students can't google their way to the truth. Education Week, 36(11), 22-28.

\section{About the Authors}
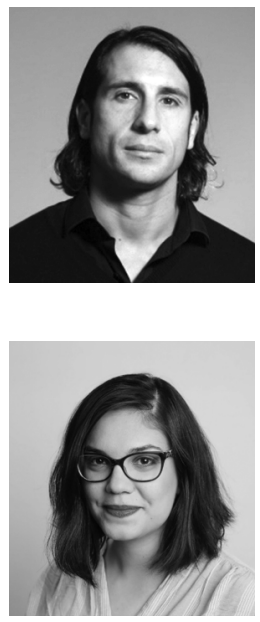

Marta Portalés-Oliva holds a PhD at the Journalism Department of the Autonomous University of Barcelona (2019) on media literacy. Since 2014 she is a Researcher at the group Gabinete de Comunicación y Educación. She studied Bachelor of Audiovisual Communication at the University of Valencia (Spain), York University in Toronto (Canada) and at the Johannes Gutenberg University Mainz (Germany) between 2009 and 2013.

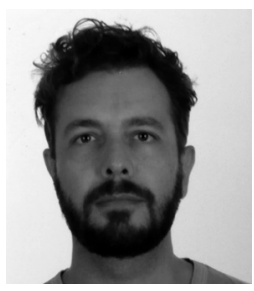

Ricardo Carniel-Bugs is a Journalist (University of Santa Cruz do Sul, Brazil) and Associate Lecturer at the Department of Journalism and Communication Sciences of the Autonomous University of Barcelona (UAB). He holds a PhD in Communication and Journalism from UAB, with recognition of European Doctor. Member of the Laboratory of Prospective and Research in Communication, Culture and Cooperation and the Mediterranean Observatory of the Communication.

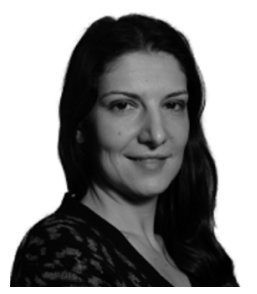

Santiago Tejedor is Director and Associate Professor at the Department of Journalism and Communication Sciences of the Autonomous University of Barcelona (UAB). He holds a PhD in Journalism and Communication Sciences from UAB and a PhD in Project Engineering from the Polytechnic University of Catalonia (UPC). He is a Member of the Communication and Education Office research group, and researches in the areas of digital journalism, media convergence and new transmedia narratives. He is also a Member of the Chair UNESCO UAB on MIL for Quality Journalism.

Laura Cervi is Serra Hunter Lecturer at the Department of Journalism and Communication Sciences of the Autonomous University of Barcelona. She holds a PhD in Political Science from the University of Pavia (Italy, 2006). Her main research interests are journalism and technology. 